\title{
System Change in Austria and Hungary 1918-1919 Comparison of the Political Aspects of the Austrian and Hungarian Crisis Management
}

\begin{abstract}
From the end of summer 1918 the political elite of Austria and Hungary counted with the possibility of war defeat. The successor states inherited the crisis of the collapsing Empire. Due to the loss factor crisis management was even more difficult for the losers - Austria and Hungary, than for the successor states considered victorious. There are several common features in the crisis management of Austria and Hungary. Both of them had to cope with the challenges of war losses and significant territory losses. The winners had tacitly acknowledged the territorial demands of the successor states before signing the peace treaties. The economies and populations of both countries became depleted, which caused strikes and revolutionary phenomena. Meanwhile the new coalition governments with social democratic participation announced a more democratic and social state in the autumn of 1918. Austrian crisis management and consolidation did not induce international intervention in Austrian domestic politics. In Hungary, the internal consolidation that began later was due to the winners' direct intervention.
\end{abstract}

\section{Numerous similarities from the beginning to the end}

When comparing the conditions of the state formation and the consolidation of Austria and Hungary in 1918 and 1920, it turns out that there were more processual similarities ${ }^{1}$ than differences. At the end of the war, both "new states" were primarily war-losers with considerable territorial losses, foreign armies stood on the periphery of their claimed territories and they had no intact, operational military forces against the foreign "invaders". The elimination from the common monarchy and the restart in both states took place without much bloodshed. ${ }^{2}$ They

SCHNECKER 2007: 110.

2 On 31 October 1918, István Tisza, former Prime Minister of Hungary (between 1903 and 1905 as well as 1913 and 1917) was murdered. Tisza was considered a symbol of Hungarian war policy, as well as Karl Stürgkh, who was murdered in October 1916, Prime Minister of Austria. There were further casualties of demonstrations and violent riots in the late autumn of 1918 , but these were not directly related to the structural breakdown of the monarchy and have not been a high number. 
also shared the fate of overburdened, bled economies and the threat of the warweary population, with its shaken social cohesion and a burdensome orientation problem. All this was expressed not only in a high degree of mobilisation of the population, which was reflected in strikes, demonstrations, violent riots and secessionist tendencies, but also in a looming increasing gap between the (capital) city and the countryside. As long as the social-democratic parties were in charge in the capitals, the Christian-conservative parties in the countryside extended their sphere of influence. In late autumn 1918 both governments faced these critical challenges with a social-democratic dominance. ${ }^{3}$ These governments consisted largely of "new" men who had no government responsibility before 1918. In both states, starting in 1918, alongside traditional centres of power, new, alternative and grassroots democratic power structures existed, such as the workers' and soldiers' councils, which, however, did not exert much influence on the redevelopment.

The new political leadership in Vienna and Budapest pursued a similar programme, which promised to establish a democratic and social state. The chosen form of government in both young states was the republic, which in Hungary was called the "People's Republic" in order to further emphasize the proclaimed popular sovereignty. Austria had a peace treaty ${ }^{4}$ since autumn 1919, Hungary since summer 1920, which entailed international de jure recognition. However, both peace treaties caused a great shock to the local population and to both political elites. The area losses as well as the refugees and optants ${ }^{5}$ from the separated areas burdened equally the still depressed economies in the long run. Political power gradually shifted from left to right in both states. In Austria, the forced political cooperation of the Social Democrats and Christian Socialists ${ }^{6}$ staggered sharply and led to the termination of their government coalition in 1920. This break was followed by an internal power shift within the Christian Social Party. ${ }^{7}$ After a sluggish consolidation, a right-wing coalition of national conservatives and the National Smallholders' Party ${ }^{8}$ ruled Hungary in 1920. This political shift to the

3 On the different positions of power of the Austrian and Hungarian Social Democrats in: MURBER 2017: 165-181.

4 In Austria, the term State Treaty is used for the treaty signed in St. Germain to make clear that the new Austria was not a legal successor to the Habsburg Monarchy, and therefore had not signed a peace treaty. In Hungary, the Trianon peace treaty was and is the common term in the public debate.

5 Both peace treaties (for Austria Section VI, Article 80, for Hungary Section VII, Article 63) made it possible to freely choose citizenship for the population of isolated areas.

6 On the position of the Christian Socialists in the early years more in: BINDER 2008: 241-260.

7 WOHNOUT 2015, 204-205.

8 Due to the parliamentary elections in January 1920, the National Smallholders' Party reached more than $50 \%$ of the seats and formed with the National Conservative party of István Bethlen a coalition in which the latter dominated. In 1922, Prime Minister Bethlen forced the merger of both parties, and as a result the National Smallholders' Party gradually moved into the background and lost its own political profile and voter base. 
right in both states was accompanied by the emergence and consolidation of effective and persistent stereotypes of the enemy in politics against the Left and Jews.

\section{The meaning of different concepts of national states}

In Hungary, there was only one state concept based on the Hungarian "supremacy", which tried to secure dominance of the Hungarian political nation" over the other nationalities and ethnic groups under the Hungarian crown in the long-term. No serious counter-concept could prevail until 1918. Thus, in late autumn 1918, the new government did not have an alternative state concept with concessions to nationalities. With considerable modification, ${ }^{10}$ the new government also claimed the entire territory of the former Hungarian kingdom in November 1918 and did not recognize the territorial claims and assignments of the successor states. However, international reality and the status of war-loser no longer favoured this Hungarian position.

In contrast, the new state leadership in Austria was able to rely on alternative nationality concepts in autumn 1918. A concept for this was provided by the Social Democrats: Otto Bauer already addressed the nationality problem of the Habsburg Empire in 1907 with possible solution approaches of a "cultural autonomy". ${ }^{11}$ The Social Democratic nationality programme ${ }^{12}$, adopted in January 1918, already contained the right of peoples to self-determination, but still issued the preservation of a common economic area. ${ }^{13}$ The German national programme of the late $19^{\text {th }}$ century by Georg Ritter von Schönere ${ }^{14}$ offered an opposite pole to this, on which the Greater Germans were able to refer to in late autumn 1918. However, both interpretations expected a loss of population and territory in comparison to the whole area of the Habsburg monarchy. At the end of the war, Austria's desire of being attached to Germany emerged as the third concept, which contained elements of the two other ideas. ${ }^{15}$

Hungary and Austria were defeated nations and the successor states, Czechoslovakia, Romania and the South Slavic state had been regarded as victors by the

9 A well-founded summary about the Hungarian state/nation concept: SZABO 2006: 201-248.

10 Oszkár Jászi, responsible minister for the question of nationality, developed a quickly failed concept, which planed a federation according to the Swiss model for the Hungarian territory. See: SZARKA 1993:189-201.

11 BAUER 1907.

12 A nationality program of the "Left", in: AUSTERLITZ 1918: 269-247.

13 HANISCH 2011: 101.

14 BAUER 2008: 263-264.

15 An overview in: Richard Saage, "Die deutsche Frage. Die Erste Republik im Spannungsfeld zwischen österreichischer und deutscher Identität", in: SAAGE 2008: 65-82. 
Entente powers. With the tacit approval of the victors, they presented the Austrian and Hungarian leaders with a fait accompli. Through their rapid military territorial occupation, the new state borders were already determined, even before the peace treaties were concluded. At the determination of the new borders, in most cases no democratic principles were decisive, but pure military power. ${ }^{16}$ Neither the new leadership in Vienna nor the one in Budapest did have a serious military counterweight. Instead of arms, they had hopes for the benevolence of the Entente powers and therefore followed a "pacifist policy", in contemporary word usage. All in all, both defeated nations accepted the emergence of new nation states in the area of the common monarchy. Yet, what hurt them most, were the territorial assignments of those territories, which they had claimed themselves, for whatever reason. Vienna accepted the area losses with the help of alternative state concepts. In the case of Carinthia, there were military steps against the South Slavic occupation, but not organised from Vienna. Regional "vigilante groups" stopped the further encroachment of southern Slavic troops. ${ }^{17}$

Despite the advance of foreign armies on the periphery, the respective governments in Budapest continued to insist on the old concept of "Greater Hungary" without being able to enforce this plan militarily. Therefore, their failure was already inevitable and ultimately led to their abdication, and also to the proclamation of the Council dictatorship. From the point of view of the victorious states, this Hungarian concept of the big state endangered the new international order of "collective security" in Central Europe, which favoured the successor states rather than the defeated states. The undesirable takeover of power by the Communists in Hungary in spring 1919 was another affront and led to a conscious intervention by the victorious powers in Hungary's process of becoming a state, which in turn generated its own momentum. The victorious powers preferred the further encroachment of the Czechoslovak, Romanian and South Slavic troops in the interior of Hungary ${ }^{18}$ than sending own troops to Hungary. However, in summer 1919 the councils rule initiated a brief, but in the end failed defence. Even after the collapse of the Council dictatorship no viable counter-concept about Great Hungary could prevail, which in turn led to the strong and consensus-building revisionism of the interwar period. The new Austria bade farewell to its old empire less painfully, more pragmatically and consensually and arranged itself more quickly - even though enforcedly - with its small state than Hungary. Therefore, in the eyes of the victors, Austria represented a smaller or rather no threat to the

16 JUDSON 2017: 563.

17 WEINMANN 2008: 119. - 183.

18 It should be noted, that already on 18 March 1919 in Paris, three days before the proclamation of the Soviet Republic, the new state borders of Hungary had been established. Only the course of the Austro-Hungarian border was not determined yet. 
new order of Central Europe, and needed less intervention in its successful political consolidation. ${ }^{19}$

\section{Differences between the participants of the restart}

On the issue of state sovereignty, there were many other similar processes in Austria and Hungary in place, such as the almost seamless adoption of the former but functioning state apparatus and the efforts to rapidly develop a state monopoly on the use of force and an executive authority with assertiveness. The old bureaucracy gave assurances of their loyalty to the new republican rulers in Vienna and Budapest. They in turn endeavoured to protect the administrative apparatus from the looming loss of loyalty of the population. However, none of the new rulers in Central Europe was able to fully alleviate the dissatisfaction of the people mobilized by the war, their urge for change and transformation. Unrest and violence spread in the cities and in the countryside. In Vienna and Budapest began the quite centrally coordinated reorganisation of the new armed forces in the form of vigilante groups already during the demobilisation of the K.u.K. Army. These groups were able to guarantee the internal order in the cities for the time being, but the establishment of the internal order in the countryside took longer. A striking difference in relation to the state sovereignty in Austria and Hungary was shown by who was a carrier and an actor in the development of the new statehood. ${ }^{20}$ On 21 October 1918, the provisional National Assembly of German Austria was constituted in Vienna by the German-speaking members of the Imperial Council $^{21}$ and they decided to form their own Austrian state - "German Austria". The government, convened on October 30 under the Social Democratic leadership of Karl Renner, consisted of the parliamentarians of the old Imperial Council. This personnel continuity between the old and the new brought along demonstrated political competences and personal networks for the new government. Due to the universal manhood suffrage of 1907, these politicians, except the German Nationalists ${ }^{22}$ were representatives of mass parties ${ }^{23}$ with their considerable followers. All parties of the Imperial Council participated in the restart and thus gave their commitment to a joint crisis management.

19 Hanns Haas noted that "the new Austria fulfilled the essential criteria of a stable statehood", in: HASS 2014: 379.

20 On minimal criteria of statehood in Austria see: HASS 2014: 371. - 384.

21 The 1911 Legislature Period of the Imperial Council was extended until 19 December 1918 by an imperially sanctioned law.

22 The German National Party is to be classified as a classic dignitary party, but was due to the Imperial Council elections in 1911 the strongest party of the Imperial Council.

23 Two of the State Secretaries, Ignaz Kaup, State Secretary for Public Health, and Johann Loewenfeld-Russ, Secretary of State for Nutrition, were previously imperial officials. 
The strength and importance of the Austrian Social Democracy among the parties was shown by their ability to attach conditions on their entry to the government on terms such as a schedule of responsibilities. ${ }^{24}$ The coalition partners were also aware of this current strength of the social democracy. They agreed to the crisis management, initiated by the "Austro-Marxists", due to the lack of an own manageable crisis programme ${ }^{25}$ Carlo Moos said that this pragmatic approach resulted in consensus-based solutions from the political legacy of the Habsburg monarchy ${ }^{26}$, but such consensus - he added - called for coexistence and reform-minded "imperial types" ${ }^{27}$ such as Karl Renner, Otto Bauer, Franz Dinghofer or Heinrich Lammasch. The broad political consensus and the social-democratic power of integration against the radical left-wing aspirations, which were not to be underestimated, in spring 1919, enabled a fairly straightforward political consolidation for German Austria. The sense of relief at these temporary successes disguised the already existing and quite divergent visions of the right and left mass parties for a time. ${ }^{28}$

For the separation of powers in the new Austria, Ernst Hanisch noted, that an "extreme parliamentary rule" emerged in response to the parliament's weak position in the monarchy. ${ }^{29}$ The end of the war entailed a high and quite politically led mobilisation of the population. The authority of the dynasty as well as the civil service and the army passed to the political parties in late autumn. ${ }^{30}$ The elections for the Constituent Assembly, held on the basis of the universal suffrage on 16 February 1919, confirmed not only this provisional consensus-oriented policy and a certain loyalty of the majority of the population to the crisis management, but also met the democratic expectations of the victorious powers. Nevertheless, an invitation to the peace negotiations took until 2 May 1919, which was also due to the priority of the negotiations on Germany's future. Apart from that, the initially successful self-assertion of the Hungarian Council dictatorship and the necessary "containment policy" of the Entente was decisive for this rather late invitation. Austria's process of state formation between 1918 and 1920 was characterised by a predominantly participatory political culture. The broad consensus of these mass parties supported the crisis management, which was also affirmed and accepted by the population in the national parliamentary elections in spring 1919 with a universal, equal and secret suffrage.

\footnotetext{
24 The tripartite conditions of the Social Democrats are in the protocol. ÖStA AdR NPA StRP Cardboard 1st Conference of the State Council on 30.10.1918.

25 HANISCH 2011: 147

26 MOSS 2016: 77.

27 MOSS 2016: 80.

28 HANISCH 1994: 266.

29 HANISCH 1994: 266.

30 BERGER 2008: 57.
} 
In contrast to Austria, there was a lack of broad political consensus in Hungary as well as of the political participation of the population until the very end. On 24 October 1918, a Hungarian National Council was constituted, which formed the core of the new government within a week. This National Council was composed of a parliamentary opposition party, ${ }^{31}$ whose head was the liberal-democratic Count Mihály Károlyi and two non-parliamentary opposition parties, the radical democrats, which was a party of urban-critical intellectuals, and the Social Democrats. Due to the census suffrage no mass parties were formed in Hungary, so the members of the National Council - except the Social Democrats - could not rely on any party network. In the eyes of broad sections of the population, Károlyi was the personification of the hope of a restart and a better future due to his democratically-social programme, which was announced for months. Under the pressure of the riots in Budapest, Emperor Charles appointed Károlyi prime minister on 31 October 1918. Although Charles relieved this government from their oath to the monarch a day later, the Károlyi government provided the royal appointment with a constitutional but merely symbolic legitimacy.

In late autumn 1918, Károlyi was, also in the eyes of the moderate national conservatives and liberal conservatives of the old power elite, a quite acceptable figurehead, who seemed suitable for representing Hungarian interests. ${ }^{32}$ Nevertheless, there was no far-reaching personnel continuity between the old and the new in the new government. The old power elite refused their participation in the crisis management and thus the division of responsibilities. The often overwhelming central and decisive role of Prime Minister Károlyi blocked the possibility for a course correction and minimized the political adaptability to the increasingly burdensome conditions.

Hungary's restart was therefore not a party-political agreement. Károlyi was the political focal point. He dominated the affairs of state not only because of his accumulation of various postions, ${ }^{33}$ but much more because of the weakness of the political parties. Károlyi's party was a minor dignitary party (Honoratiorenpartei)

31 Despite the prohibited universal suffrage in Hungary, the Hungarian Parliament met throughout the war. However, due to the prohibited universal suffrage, it consisted only of dignitary parties.

32 Even Ex-Prime Minister István Tisza argued in the parliament on 22 October 1918, that Károlyi had the necessary relational capital for Hungary to the West, to the Entente powers. In: Képviselöházi Napló, 22. October 1918. Count Pál Teleki and Count István Bethlen, both prime ministers of the inter-war period did not distance themselves from Károlyi's policy at that moment.

33 From 31 October 1918 Károlyi was the Prime Minister and the Minister for Foreign Affairs, from 12 December 1918 he also took over the representation of the Ministry of Defence and between 11 January and 21 March 1919 he served as President of Hungary. It also happened in the case of Karl Renner who, in addition to the Chancellorship, also took over other ministerial departments, such as the Ministry of the Interior, the Office of the Interior, Education and Foreign Affairs. 
with narrow social basis. The Hungarian Social Democrats, like their Austrian counterparts, had the densest and most comprehensive party network and a viable programme for the future, which enabled them to participate in the redevelopment. ${ }^{34}$ But their sphere of influence was more modest than that of the Austrian Party members. In consequence of their extra-parliamentary opposition, the party leadership did not possess the competences and experiences of policy-making, which the like-minded Austrians already had in autumn 1918.

The Austrian provisional legislation was recruited from the old Imperial Council, had three equal presidents and was constituted on the basis of the new elections in February 1919. By contrast, the democratic legitimacy of the Hungarian legislation was far less pronounced. The National Council, convened on 24 October, an exclusive centre of power without democratic legitimacy, with its claim to legislative and executive powers, was composed, legally not entirely clear, of representatives of the administration, parties and various political and administrative bodies. On behalf of the National Council, the Károlyi government provided itself, in addition to the executive, also with legislative power on the basis of the Public Law of 22 November 1918. ${ }^{35}$

In Hungary, as in Austria, a law was passed on universal, equal and secret suffrage. But the constituent National Council elections were postponed until April 1919. According to official justification, elections without the participation of the occupied territories would have equalled de jure recognition of the territorial losses of Great Hungary. The proclamation of the Soviet Republic finally prevented the elections announced for April. This allowed neither the democratic opinion formation of the population on the crisis management nor the constitution of a constituent National Council. ${ }^{36}$ The phenomena of the executive and legislative in the Hungarian state formation process reflected a predominantly paternalistic political culture based on a subject mentality.

\section{Divergent international impulses in the name of "collective security" 37}

Only in the last year of the war did the new concept of a Central European order without the Habsburgs emerge..$^{38}$ But on how this Central Europe of small

34 The government programme in late 1918 was largely based on the Social Democrats' programme announced on 8 October.

35 Az 1910. évi június hó 21-ére hirdetett országgyülés képviselöházának irományai, LXIV.m 1918: 412.

36 The first parliamentary elections took place in January 1920 in those electoral districts where no foreign armies were stationed. The elections resulted in a right-wing conservative parliamentary majority and right-wing coalition government with the participation of a Christian-Social and a Smallholders' Party. The Social Democrats kept away from these National Council elections in protest against the "white terror".

37 Anselm Doering-Manteuffel, "Kollektive Sicherheit, Demokratie und Entspannungspolitik. Der historische Ort des Völkerbunds in der Geschichte der Moderne", in: DOERING-MANTEUFFEL 2014: 305-316. 
states should look, there were different, competing concepts in 1918, one of the "East" and one of the "West". Under the right of self-determination of the peoples, Vladimir Ilyich Lenin proclaimed a self-imposed, but rather theoretical, above all territorial sovereignty. Woodrow Wilson, American President, understood the self-government of a democratic regime under the same buzzword. ${ }^{39}$ In the last year of the war, both "ideological offensives" 40 reached the Habsburg Empire, thus accelerating its process of disintegration. ${ }^{41}$ Both interpretations found a strong repercussion in the Central European political and public discourse, with territorial independence and sovereignty being the undisputed key objective for the nations. In the political discourse emerged an additional link between demands for national independence and more democracy. ${ }^{42}$

In 1918, "democracy" became "suddenly" popular in Central Europe and was regarded as an alternative to the authoritarian "hated old", which could be equated with the Habsburg Monarchy and its weaknesses as well as with the war and its suffering. "The future seemed to belong to democracy." ${ }^{43}$ The new political actors hoped that the proclamation of a new democratic order would also lead to greater sympathy by the victors and thus to better peace conditions. On the contrary, there was a lack of an already established democratic-political culture. Apart from social democracy and some radical intelligentsia, there was no democratic tradition behind the new political slogan, let alone an anchoring in broad sections of the population. This ultimately led to the early failure of this democratic experiment everywhere in Central Europe - except in Czechoslovakia. This export of democracy at the end of the war took place in a very troubled economic situation, so it was unable to bridge the socio-economic problems that had already arisen before the war as a result of the transition from an agricultural society to an industrial society.

On 16 October 1918, Emperor Charles offered in his manifesto the official consent to national self-organisation in the form of national councils, but within a federal framework. ${ }^{44}$ In doing so, he legalised the already established national councils in Zagreb and Krakow and gave the legitimising impetus for their creation in Prague, Vienna and Budapest. ${ }^{45}$

38 A detailed and well-founded account of the role of the Habsburg Monarchy in the war can be found in: RAUCHENSTEINER 2013.

40 RAUCHENSTEINER 2008: 21-41.

RAUCHENSTEINER 2008: 38.

On the catalytic role of the Russian revolutions in: MORITZ 2017: 48.

42 KRÜGER 1993: 101.

43 HANISH 1994: 267.

44 RUMPLER 1966

45 The imperial manifesto only referred to the Austrian half of the empire. Opinions and literature differ about whether this is due to the emperor's self-decision or to the express request of the Hungarian leadership. 
International recognition through a peace treaty presupposed not only the criteria of the de facto statehood (national territory, state population and state authority ${ }^{46}$ but also democratic leadership, a government recognised and accepted by the majority of the population, ${ }^{47}$ which had been regarded as a grant for internal stability and international order. According to these intentions of the democratic victorious states, democratic legalization of the new state power served to stabilize and protect the new international state system that they had established. If the new de facto states endangered the new concepts of order of the victorious states, the latter acted with different but usually modest methods. The "imperial viewpoint" of the Entente enabled the decision-makers in Paris to hand over territories of a state, endangering the new and desired order of Central Europe, to a preferred country. ${ }^{48}$

Austria and Hungary were the losers of the war and were perceived as responsible for the war, which was tantamount to foreign policy isolation. The basic guidelines of Austria's and Hungary's foreign policy were the same. The focus was on the so-called "pacifist" policy, which was based on the hope of the US President Woodrow Wilson and his programme. Neither Vienna nor Budapest was able to counteract the occupations militarily. For the time being, they expected these secessions of territory to be temporary and that the "just" peace treaty would cancel at least part of them. Therefore, an early peace agreement was desired. Compared to Hungary, the new Austria had a foreign policy that hardly aroused any intervention of the victorious powers, except the connection efforts to Germany. Until the Council dictatorship, Prime Minister Károlyi made the foreign policy of Hungary, which in contrast led to an increasing influence on Hungary's domestic affairs by the Entente powers.

Thanks to Bauer's tactical and diplomatic skills, ${ }^{49}$ Austria was able to exploit its own problematic food supply and thus exert a moderate, but certainly existing influence on foreign policy conditions. ${ }^{50}$ At the end of the war, the question of supply bottlenecks became the focus of political action in Vienna and these experiences strengthened the belief in the inability of small Austria to survive and the necessity of a connection to Germany. In late autumn 1918, the Austrian

\footnotetext{
46 According to Georg Jellinek's definition, a state is constituted by the following three elements: national territory, state population and state authority, in: JELLINEK 1914: 394-434.

47 This democratic legalization of the new state power expected by the victorious powers should be confirmed by means of universal suffrage and parliamentary elections. 
government already made several appeals to the international community to save its urban population from starvation. Negotiations in Switzerland and in Vienna began between representatives of Austria and the victorious powers regarding possible aid. ${ }^{51}$ As a result, international aid was given to Austria. Non-governmental organisations, the Red Cross, the Quakers and the Swedish Mission distributed relief supplies in Austria. Herbert Hoover, the US Food Commissioner for Europe, gave a loan of 48 million dollars for the Renner government for the immediate purchase of food. ${ }^{52}$

This international aid could be interpreted as a success of the new Austrian foreign policy, which strengthened the internal legitimacy of the new regime. Furthermore, the negotiations and the received aid were regarded as a de facto recognition of the existence of the new Austrian state. In addition, personal contacts and communication with representatives of the Entente powers about the country's problems brought positive output from the negotiations. Foreign Minister Bauer skilfully juggled with the Austrian dependence resulting from the threatening supply bottleneck. By arguing that Austria needed the help of the Entente, he rejected a Bolshevik experiment with Hungary ${ }^{53}$ and its own population. The "weapon" of supply problems was usable in many ways. The food capacity of the claimed area for Vienna's food supply also played a role among the Austrian arguments for connecting Western Hungary ${ }^{54}$ to Austria.

In spring 1919, another, but unexpected means of exerting pressure was added to the inventory of Austrian political arguments for action. The proclamation of the Hungarian Council dictatorship on 21 March 1919 frightened the decision-makers in Paris, even though they already had knowledge of left-wing radical activities in Budapest. ${ }^{55}$ The victorious powers' containment policy towards Austria was based on concessions, such as the removal of the economic blockade and the invitation to peace negotiations ${ }^{56}$ in Paris, but also on threats with the suspension of Allied food supplies in the event of a council experiment.

51 LOEWENFELD-RUSS 1986: 231-282.

52 BERGER 2008: 60.

53 ÖStAAdR NPA Nachlass Bauer, Karton 234. Umschlag IX. d, N. 393-408. In Hungarian SZÍNAI 1994: 449-470.

54 Today it is the province of Burgenland.

55 Colonel Sir Thomas Cunningham, head of the British Military Commission in Vienna, acted strongly against left-wing extremist tendencies in Austria and feared the spread of Bolshevism from Hungary to Vienna, about which he wrote numerous reports.

56 The Austrian representatives, as well as the German and later the Hungarian colleagues, were isolated and could not actively participate in the negotiations. They received the conditions in writing, to which they also had to reply in writing, only exchanges of notes took place. Among the representatives of the defeated, only the chairman of the Hungarian delegation, Count Albert Apponyi, was allowed to make a plea for the Hungarian arguments, which found little or no repercussion for the improvements of the Hungarian peace conditions. 
Hungarian foreign policy operated under less favourable conditions than Austrian foreign policy. The lack of international recognition weighed more on Hungary, although it pursued the same pro-Western, Entente-friendly policy like Austria. The only foreign policy result was the Military Convention of 13 November 1918 in Belgrade, presented by the Károlyi government. In this ceasefire agreement, the southern and eastern demarcation lines of Hungary were defined by Entente military representatives and this therefore meant a de facto recognition of Hungary. However, these were ignored by further occupations of neighbouring countries, especially after the proclamation of the Council dictatorship. The lack of foreign policy successes and the complex domestic political and economic crisis made it difficult to consolidate Károlyi's weak coalition government and encouraged the belief in the need for radical attempts as a solution.

The Hungarian Communists, sent and supported by Moscow, acted particularly purposefully to undermine the overtaxed state power. The increasingly weakening Hungarian statehood with shrinking internal and external sovereignty aroused more and more attention and concern among the decision-makers in Paris. The establishment of the Council dictatorship in Hungary developed an international momentum against Hungary under the leadership of the victorious powers. The foreign policy suspension of Hungary's weak statehood and the lack of sovereignty were also reflected in the fact that the Bolshevik dictatorship in Hungary had been established with foreign policy support from Soviet Russia. But the country also needed the active intervention of the West to induce consolidation after the Council dictatorship at the beginning of August 1919. After the communist dictatorship, the victorious powers used a policy of carrot and stick on Hungary: the economic blockade was lifted and Hungary was invited to peace negotiations, but very hard and painful peace conditions were presented and imposed on them. In 1920, the international community could show more "sympathy and compassion" to a starving small state like Austria, which resisted the hated communism, than to the small state of Hungary, which insisted on "Greater Hungary", sank into chaos and communism and subsequently into revisionism. 


\section{Bibliography}

Archival sources

Austrian State Archive (ÖStA), Archiv der Republik (AdR), Neues Politisches Archiv (NPA), Nachlass Bauer, Karton 234. Umschlag IX. d, N. 393-408.

ÖStA AdR NPA StRP, Cardboard 1st Conference of the State Council on 30.10.1918.

\section{Published sources}

AUSTERLITZ, Friedrich. 1918. Der deutsch-österreichische Staat, Der Kampf 11: 713718.

BAUER, Otto. 1907. Nationalitätenfrage und Sozialdemokratie. Wien: Verlag der Wiener Volksbuchhandlung Ignaz Brand.

Az 1910. évi június hó 21-ére hirdetett országgyülés képviselöházának irományai, LXIV.m (1918.)

Képviselőházi Napló XLI (1918).

\section{Literature}

BAUER, Kurt. 2008. Das deutschnationale Lager. In Das Werden der Ersten Republik. Der Rest ist Österreich. Volume I., eds. Helmut Konrad and Wolfgang Maderthaner, 261-280. Wien: Carl Gerold's Sohn Verlagsbuchhandlung KG.

BERGER, Peter. 2008.Kurze Geschichte Österreichs im 20. Jahrhundert. Wien: WUV Universitätsverlag der Hochschülerschaft an der Universität Wien.

BINDER, Dieter A. 2008. Fresko in Schwarz? Das christlichsoziale Lager. In Das Werden der Ersten Republik. Der Rest ist Österreich. Volume I., eds. Helmut Konrad and Wolfgang Maderthaner, 241-260. Wien: Carl Gerold's Sohn Verlagsbuchhandlung KG.

DOERING-MANTEUFFEL, Anselm. 2014. Kollektive Sicherheit, Demokratie und Entspannungspolitik. Der historische Ort des Völkerbunds in der Geschichte der Moderne. In Teilung überwinden. Europäische und internationale Geschichte im 19. Und 20. Jahrhundert. Festschrift für Wilfried Loth, eds. Michaela Bachem-Rehm, Claudia Hiepel, Henning Türk, 305-316. München: Oldenbourg Wissenschaftsverlag.

FISH, Jörg. 2010. Das Selbstbestimmungsrecht der Völker. Die Domestizierung einer Illusion. München: C. H. Beck.

HAAS, Hanns. 2014. Ein verfehlter Start? Die Anfänge Österreichs 1918 bis 1920. Zeitgeschichte 41/6: 371-384.

HANISCH, Ernst. 1994. Der lange Schatten des Staates. Österreichische Gesellschaftsgeschichte im 20. Jahrhundert. Wien: Ueberreuter.

HANISCH, Ernst. 2008. Im Zeichen von Otto Bauer. Deutschösterreichs Außenpolitik in den Jahren 1918 bis 1919. In Das Werden der Ersten Republik. Der Rest ist Österreich. Volume I., eds. Helmut Konrad and Wolfgang Maderthaner, 207-222. Wien: Carl Gerold's Sohn Verlagsbuchhandlung KG. 
HANISCH, Ernst. 2011. Der große Illusionist. Otto Bauer (1881-1938). Wien-KölnWeimar: Böhlau.

JELLINEK, Georg. 1914. Allgemeine Staatslehre. Berlin: Häring.

JUDSON, Pieter M. 2017. Habsburg. Geschichte eines Imperiums 1740-1918. München: C. H. Beck.

KRÜGER, Peter. 1993. Die Friedensordnung von 1919 und die Entstehung neuer Staaten in Ostmitteleuropa. In Das Jahr 1919 in der Tschechoslowakei und in Ostmitteleuropa, eds. Hans Lemberg and Peter Heumos, 93-115. München: Oldenbourg Wissenschaftsverlag.

MOOS, Carlo. 2016. Habsburg post mortem. Betrachtungen zum Weiterleben der Habsburgermonarchie. Wien-Köln-Weimar: Böhlau.

MORITZ, Verena. 2017. 1917. Österreichische Stimmen zur Russischen Revolution. Salzburg: Residenz.

MURBER, Ibolya. 2017. Die ungarischen und österreichischen Sozialdemokraten und die russischen Revolutionen 1917. In Russische Revolutionen 1917. Presseanalysen aus Vorarlberg und internationale Aspekte, 165-181. Feldkirch: Rheticus-Gesellschaft.

MURBER, Ibolya. 2018. Die Staatswerdung Österreichs und Ungarns zwischen 1918 und 1920 im Vergleich. In: Die junge Republik, 188-201. Wien: Vogelsang Institut.

RAUCHENSTEINER, Manfried. 2008. „Das neue Jahr machte bei uns einen traurigen Einzug“. Das Ende des Großen Krieges. In Das Werden der Ersten Republik. Der Rest ist Österreich. Volume I., eds. Helmut Konrad and Wolfgang Maderthaner, 21-41. Wien: Carl Gerold's Sohn Verlagsbuchhandlung KG.

RAUCHENSTEINER, Manfried. 2013. Der Erste Weltkrieg und das Ende der Habsburgermonarchie 1914-1918. Wien-Köln-Weimar: Böhlau.

RUMPLER, Helmut. 1966. Das Völkermanifest Kaiser Karls vom 16. Oktober 1918. Letzter Versuch zur Rettung des Habsburgerreiches. München: R. Oldenbourg.

LOEWENFELD-RUSS, Hans. 1986. Im Kampf gegen den Hunger. Aus den Erinnerungen des Staatssekretärs für Volksernährung 1918-1920. München: Oldenbourg Wissenschaftsverlag.

SAAGE, Richard. 2008. Die deutsche Frage. Die Erste Republik im Spannungsfeld zwischen österreichischer und deutscher Identität. In Das Werden der Ersten Republik. Der Rest ist Österreich. Volume I., eds. Helmut Konrad and Wolfgang Maderthaner, 65-82. Wien: Carl Gerold's Sohn Verlagsbuchhandlung KG.

SCHNECKER, Ulrich 2007. Fragile Staatlichkeit und State-building. Begriffe, Konzepte und Analyserahmen. In Staatszerfall und Governance, eds. Marianne Beisheim, Gunnar Folke Schuppert, Marianne Beisheim, Gunnar Folke Schuppert, 98-121. Baden-Baden: Nomos.

SZABÓ, Ildikó. 2006. Nemzetfogalom és nemzeti identitás a dualizmus korában és a Horthy-korszakban. Politikatudományi szemle 15/1: 201-248.

SZARKA, László. Die Nationalitätenfrage im Auflösungsprozess des historischen Ungarn 1918-1920. In Das Jahr 1919 in der Tschechoslowakei und in Ostmitteleuropa, eds. Hans Lemberg and Peter Heumos, 189-201. München: Oldenbourg Wissenschaftsverlag.

SZÍNAI, Miklós. 1994. A Magyar Tanácsköztársaság és Ausztria kapcsolataihoz: Otto Bauer levele Kun Bélához. Századok 103/2-3: 449-470. 
WEINMANN, Ute. 2008. Die südslawische Frage und Jugoslawien, Grenzziehung im Süden Österreichs unter besonderer Berücksichtigung der Kärntenproblematik. In Das Werden der Ersten Republik. Der Rest ist Österreich. Volume I., eds. Helmut Konrad and Wolfgang Maderthaner, 119-138. Wien: Carl Gerold's Sohn Verlagsbuchhandlung KG.

WOHNOUT, Helmut. Kontinuitäten und Brüche der österreichischen Parteigeschichte am Beispiel der Christlichsozialen von den 1880er Jahren bis 1945. In Auf der Suche nach Identität. Festschrift für Dieter Anton Binder, eds. Georg Kastner, Ursula Mindler-Steiner, Helmut Wohnout, 199-220. Wien: LIT.

Promjena sistema u Austriji i Mađarskoj 1918. - 1919. Usporedba političkih aspekata austrijske i mađarske krize uprave

Austro-Ugarska Monarhija izgubila je Prvi svjetski rat. Od kraja ljeta 1918. politička elita obiju zemalja računala je na mogućnost ratnog poraza. Događanja u Rusiji 1917. godine imala su simboličko značenje; osnažila su unutarnju krizu dualne monarhije. Unatoč tomu, nije unutarnja kriza izazvala raspad ovog višenacionalnog carstva, nego vojni poraz i promjene u međunarodnom odnosu snaga.

Zemlje nasljednice naslijedile su krizu raspadajućeg carstva. Zbog poraza, kriza upravljanja bila je još teža za gubitnike - Austriju i Mađarsku, nego za zemlje nasljednice koje su smatrane pobjednicama. Nekoliko je zajedničkih obilježja krize upravljanja u Austriji i Mađarskoj. Obje su se zemlje suočavale s izazovima koje je donio ratni poraz i znatni teritorijalni gubitci. Pobjednici su prešutno priznali teritorijalne zahtjeve zemalja nasljednica i prije potpisivanja mirovnih sporazuma. Gospodarstva i stanovništvo obiju zemalja bili su iscrpljeni, što je uzrokovalo štrajkove i revolucionarne pojave. U međuvremenu, nova koalicijska vlada sa socijaldemokratskom većinom najavila je u jesen 1918. demokratskiju i socijalniju državu. Austrijska kriza uprave i konsolidacija nisu izazvale međunarodnu intervenciju u austrijskuunutarnju politiku. U Mađarskoj, konsolidacija koja je započela krajem ljeta 1919. bila je izravna intervencija pobjednika.

Ključne riječi: Habsburška Monarhija, Austrija, Ugarska, demokracija.

Keywords: Habsburg Empire, Austria, Hungary, democracy, crisis management.

Ibolya Murber

Eötvös Loránd University, Budapest Budapest, Egyetem tér 1-3, 1053 Hungary murber.ibolya@sek.elte.hu 


\section{FILOZOFSKI FAKULTET SVEUČILIŠTA U ZAGREBU \\ ZAVOD ZA HRVATSKU POVIJEST \\ INSTITUTE OF CROATIAN HISTORY \\ INSTITUT FÜR KROATISCHE GESCHICHTE}

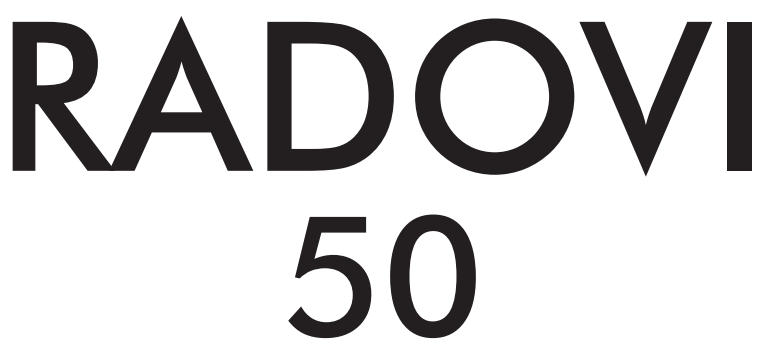

BroJ 1

ZAVOD ZA HRVATSKU POVIJEST

FILOZOFSKOGA FAKULTETA SVEUČILIŠTA U ZAGREBU

\section{FF press}

ZAGREB 2018. 


\title{
RADOVI ZAVODA ZA HRVATSKU POVIJEST FILOZOFSKOGA FAKULTETA SVEUČILIŠTA U ZAGREBU
}

\author{
Knjiga 50, broj 1
}

\author{
Izdavač / Publisher \\ Zavod za hrvatsku povijest \\ Filozofskoga fakulteta Sveučilišta u Zagrebu \\ FF-press \\ Za izdavača / For Publisher \\ Vesna Vlahović Štetić \\ Glavni urednik / Editor-in-Chief \\ Hrvoje Gračanin \\ Izvršni urednik / Executive Editor \\ Nikola Anušić \\ Uredništvo / Editorial Board
}

Bruna Kuntić-Makvić (stara povijest/ancient history), Zrinka Nikolić Jakus (srednji vijek/

medieval history), Hrvoje Petrić (rani novi vijek/early modern history), Željko Holjevac (moderna povijest/modern history), Tvrtko Jakovina (suvremena povijest/contemporary history),

Silvija Pisk (mikrohistorija i zavičajna povijest/microhistory and local history),

Zrinka Blažević (teorija i metodologija povijesti/theory and methodology of history)

Međunarodno uredničko vijeće / International Editorial Council

Denis Alimov (Sankt Peterburg), Živko Andrijašević (Nikšić), Csaba Békés (Budapest), Rajko

Bratož (Ljubljana), Snježana Buzov (Columbus, Ohio), Svetlozar Eldarov (Sofija), Toni Filiposki

(Skopje), Aleksandar Fotić (Beograd), Vladan Gavrilović (Novi Sad), Alojz Ivanišević (Wien),

Egidio Ivetić (Padova), Husnija Kamberović (Sarajevo), Karl Kaser (Graz),

Irina Ognyanova (Sofija), Géza Pálffy (Budapest), Ioan-Aurel Pop (Cluj),

Nade Proeva (Skopje), Alexios Savvides (Kalamata), Vlada Stanković (Beograd),

Ludwig Steindorff (Kiel), Peter Štih (Ljubljana)

Izvršni urednik za tuzemnu i inozemnu razmjenu /

Executive Editor for Publications Exchange

Martin Previšić

Tajnik uredništva / Editorial Board Assistant

Dejan Zadro

Adresa uredništva/Editorial Board address

Zavod za hrvatsku povijest, Filozofski fakultet Zagreb, Ivana Lučića 3, HR-10 000, Zagreb

Tel. ++385 (0)1 6120 150, 6120 158, faks ++385 (0)1 6156879

Časopis izlazi jedanput godišnje / The Journal is published once a year

Časopis je u digitalnom obliku dostupan na / The Journal in digital form is accessible at

Portal znanstvenih časopisa Republike Hrvatske „Hrčak“ http://hrcak.srce.hr/radovi-zhp

Financijska potpora za tisak časopisa / The Journal is published with the support by Ministarstvo znanosti, obrazovanja i športa Republike Hrvatske

Časopis je indeksiran u sljedećim bazama / The Journal is indexed in the following databases: Directory of Open Access Journals, EBSCO, SCOPUS, ERIH PLUS, Emerging Sources Citation Index - Web of Science 


\title{
Naslovna stranica / Title page by
}

Iva Mandić

\section{Grafičko oblikovanje i računalni slog / Graphic design and layout Marko Maraković}

\author{
Lektura / Language editors \\ Marijana Ivić (hrvatski / Croatian) \\ Dražen Nemet (engleski / English)
}

Tisak / Printed by

Tiskara Zelina, Sv. Ivan Zelina

Naklada / Issued

200 primjeraka / 200 copies

Časopis je u digitalnom obliku dostupan na Portalu znanstvenih časopisa Republike Hrvatske „Hrčak“ http://hrcak.srce.hr/radovi-zhp

The Journal is accessible in digital form at the Hrcak - Portal of scientific journals of Croatia http://hrcak.srce.hr/radovi-zhp 